\title{
Chen GoldBerg
}

ORCID 0000-0002-3491-8480

Gordon Academic College, Haifa

Higher Studies, Israel

GAMAL ISHAN

ORCID 0000-0002-1775-6926

Sakhnin College

Higher Studies, Israel

\section{PEDAGOGICAL BELIEFS \\ OF ARAB MATHEMATICS AND RELIGION TEACHERS IN NORTHERN ISRAEL}

Aвstract. Goldberg Chen, Ishan Gamal, Pedagogical Beliefs of Arab Mathematics and Religion Teachers in Northern Israel [Przekonania pedagogiczne arabskich nauczycieli matematyki i religii w północnym Izraelu]. Studia Edukacyjne nr 58, 2020, Poznań 2020, pp. 279-290. Adam Mickiewicz University Press. ISSN 1233-6688. DOI: 10.14746/se.2020.58.15

The aim of the current study is to examine the relationship between the pedagogical beliefs of teachers and their profession and to examine how this relationship affects teachers' self-efficacy perception, satisfaction, and other functional characteristics of the teacher within the educational system. More specifically, the study seeks to compare the pedagogical beliefs of Muslim teachers who teach Religion subjects (i.e. Islamic studies) and the pedagogical beliefs of teachers of secular studies (i.e. Mathematics). According to the proposed research model, the teaching profession (that is, teaching religious Islam or teaching Mathematics) divergently affects the nature of teachers' pedagogical beliefs, through which they function and perceive their role as teachers. The focus of our study is Arab teachers of Islam versus Arab mathematics teachers, who reflect traditional pedagogical beliefs on two levels, first by selecting teachers belonging to the Muslim minority in Israel, but also in the context of the distinction between teaching. The study hypothesis suggests that there is a difference between the pedagogical beliefs of teachers of Islamic studies and the pedagogical beliefs of Mathematics teachers. In particular, it seeks to examine the claim that teachers of Islamic studies will have a strong traditional belief and weaker constructive belief compared to teachers of secular studies. This research hypothesis has not been confirmed. In fact, except in terms of teachers' satisfaction, no differences between the two types of teachers were found. This might indicate a change in the Arab society which deviates from the traditional Islamic halakhic approach that focuses almost entirely on religious studies and adopts a more modernized and liberal educational approach, centered on a Western education model and secularism.

Key words: pedagogical beliefs, mathematics teachers, religion teachers, Arab teachers 


\section{Introduction}

The Israeli education system places relatively much emphasis on the importance of the teacher within the educational layout. ${ }^{1}$ According to Kupfferberg \& Niederland ${ }^{2}$ teachers are viewed as broad-minded and knowledgeable educators, both in class and social context. These expert teachers are required to be well versed in the field of knowledge, to have high-level teaching and communication skills, and to be able to lead change. Thus, for instance, teachers are encouraged to acquire advanced academic degrees, and to broaden and deepen their disciplinary knowledge and expertise by engaging in and contributing to the constant development of teachers' training outlines of inter-disciplinary and intra-disciplinary programs. ${ }^{3} \mathrm{How}$ ever, such emphasis of the Israeli education system most often than not is assessed only from the student's perspective, specifically focusing merely on grades and achievements, and neglecting other unquantifiable aspects of education such as pleasure, Interpersonal Interactions, and meaningful values. ${ }^{4}$ While teachers' everyday lives are anchored by values and beliefs, it should also be recognized that such values and beliefs are expressed in the teachers' teaching, their relationships with students and peers, their choices in assessment methods as well as curricular choices. ${ }^{5}$ This is summarized by the concept of Pedagogical Belief, as the worldview that guides teachers during their work. ${ }^{6}$

Accordingly, this study seeks to add to existing knowledge regarding teachers' beliefs in two aspects. First, by focusing on the teachers themselves and how they experience the processes of teaching, and, second, by considering teachers' pedagogical beliefs in view of the field of teaching as predictors teachers' attitudes toward main characteristics of their work. The aim of the current study is to examine the relationship between the pedagogical beliefs of teachers and their profession, and to examine how this relationship affects teachers' self-efficacy perception, satisfaction, and other functional characteristics of the teacher within the educational system. For this purpose, Arab teachers of Islam studies and Arab mathematics teachers' pedagogical beliefs were compared. This setup allowed to use teaching profession (that is, teach-

\footnotetext{
${ }^{1}$ I. Kupfferberg, D. Niederland, To be a teacher in Israel in the 21st century, [in:] Building Professional Identity: Professional training and development processes for teachers in Israel, Eds. R. Kloyer, L. Kozminsky, Moffett Institute, Tel Aviv, 2012, p. 411-435.

${ }^{2}$ Ibidem.

${ }^{3}$ Ibidem.

${ }^{4}$ Ibidem.

${ }^{5}$ S.E. Barrett, The Impact of Religious Beliefs on Professional Ethics: A Case Study of a New Teacher, Canadian Journal of Education, 2015, 38, 3, p. 1-21.

${ }^{6}$ H. Fives, M.G. Gill, International handbook of research on teachers' beliefs, Routledge, 2014.
} 
ing religious Islam or teaching Mathematics) as proxy for traditional-religious vs. contemporary-secular nature of teachers' pedagogical beliefs, through which they function and perceive their role as teachers.

\section{Literature review \\ A brief overview of the Israeli education system}

The social and cultural complexity and diversity of Israeli society are reflected in its education system. ${ }^{7}$ This heterogeneity is expressed in different layers of the Israeli education system' structure, in its' budgeting, through the existence of various institutions, and by the structural adaptation to the needs of different sectors of the Israeli society. According to a special report to the Israeli parliament committee for education, culture, and sport ${ }^{8}$ state, the Israeli education system is usually viewed according to the following four aspects:

- Age: a division according to students' age and educational progress, i.e. pre-elementary education, elementary education, post-elementary education which includes middle-school and high-school education, and post-secondary and academic studies;

- Legal status: a division according to institutions' degree subordination and responsiveness to state supervision. This division distinguish betweenformal education (i.e. State or local authorities' owned educational institutions declared as official institutions, usually elementary schools), recognized non-formal education (i.e. institutions that are not state-owned but have accepted some degree of oversight from the state. Compared with the formal institutions, these institutions are only $75 \%$ budgeted by the state but enjoy more freedom in accepting students, hiring teachers, and setting a curriculum. Most of middle- and high-schools are among these institutions), and $e x-$ emption institutions (religious institutes which are not supervised by the state, usually with their own curriculum which does not include core subjects such as English or STEM. Despite their independent stance, these institutions receive state budgeted support of 55-60\% compared with formal institutions);

- Supervision type: a division of educational institutions according to the educational supervision. This division considers the non-religious (Jewish and non-Jewish) education, the Zionistic-Jewish education, and the orthodox-Jewish education. the two formers are supervised by the state while the latter is supervised by communal-political Associations;

${ }^{7}$ E. Veissblei, A. Vieneger, The Education System in Israel - Selected Issues in the Field of the Knesset's Education, Culture and Sports Committee, Culture, and Sport Committee, Israel Knesset, 2015.

${ }^{8}$ Ibidem. 
- Sector: this division distinguish between the Jewish sector, as well as Non-Arab students (1,798 thousand students, $76 \%)$, and Non-Jewish sector including Muslim (391 thousand students, 17\%), Bedouin (123 thousand students, $5 \%$ ), Druze (41 thousand students, $2 \%$ ), and Cherkasy students (approximately 1000 students, $0.04 \%$ of the students). ${ }^{9}$

According to the Israeli CBS 2019 yearly census, ${ }^{10}$ the Arab secondary education sector included 11,315 teaching jobs, of which $57.7 \%$ were held by women, $16.7 \%$ by teachers up to the age of $29,20.1 \%$ by teachers' age 50 and over, and $93.6 \%$ held by academic teachers. On average, these teachers worked 32.1 hours per week with an average of 13.5 years of tenure.

Despite improvement in all learning metrics - i.e. language (Hebrew or Arabic, respectively), English, mathematics, and STEM-longitudinal monitoring of student achievements indicate a persistent gap between Jewish and Arab students in favor of Jewish students. ${ }^{11}$

Secondary Arab education requirements does not view Islam studies as obligatory. Authority regarding the teaching of Islamic religion have been fully delegated to school principals, and it is commonly agreed that these studies include theoretical as well as practical subjects. ${ }^{12}$ As such, an Islam student is expected to master a basic theoretical body of knowledge, as well as behave and follow according to the religious Islamic tradition. Accordingly, Islam teaching requires the teacher to be a religious Muslim and identify with the content they teach. Thus, acquiring theoretical knowledge is not enough. Rather, Islam teaching that is a matter of great personal and emotional involvement on the part of the teacher. ${ }^{13}$

\section{Teachers' pedagogical beliefs}

Despite its' intuitive nature, teachers' pedagogical beliefs as an academic construct is rather ambiguous. According to Fisher, ${ }^{14}$ the guidelines and framework in which teachers work are a product of an epistemological, axio-

${ }^{9}$ Ministry of Education, Opening 2019-2020 school year public announcement by Israel's Education minister, 2019; https://edu.gov.il/owlHeb/AboutUs/newyeartahaa/Pages/year -opening.aspx.

${ }^{10}$ Central Bureau of Statistics, Teaching Staff in Secondary Education by Selected Characteristics, Yearly census report, Jerusalem, Central Bureau of Statistics, 2019.

${ }^{11}$ E. Veissblei, A. Vieneger, The Education System in Israel.

${ }^{12}$ S. Ilues, The pedagogical beliefs of Bible and the Oral Law teachers of girls in the religious high school, PhD Thesis, Bar-Ilan University, 2004.

${ }_{13}$ A. Mahajhna, D. Kfir, Islamic Studies in the Age of Globalization: The Case of Arab Teacher Training in Israel, Beit Berl Academic College, 2012.

${ }^{14}$ Y. Fisher, Exploration of values: Israeli teachers' professional ethics, Social Psychology of Education, 2013, 16, 2, p. 297-315. 
logical and ontological set of beliefs that serves them to clarify truths, determine what is right and what is not, what is or should be considered as appropriate, and generally to wonder about human nature and existence.

Others ${ }^{15}$ regard teachers' beliefs as a psychological understanding about the essence of the surrounding world, as a sieve through which their views are expressed or rationalized into certain actions. For instance, teachers' perceptions of mathematics and its' role will influence teachers' attitudes to mathematics as a teaching profession and most probably will play a significant role in their teaching methods. ${ }^{16}$

A more "flexible" definition was provided by Barrett, ${ }^{17}$ according to which teachers' beliefs reflectwhat teachers believe to be true. Such definition is not necessarily based on result, experience or judgment. As shown by Peterson ${ }^{18}$ regarding Christian-Evangelist teachers, such beliefs were common in many religious studies.

However, in the present study we adopted Fives ${ }^{19}$ conceptualization, according to which pedagogical beliefs represent a specific set of beliefs that reflect how teachers understand teaching and the values they attribute to this understanding.

\section{Pedagogic beliefs, perception of the teachers' functioning characteristics}

Fives $^{20}$ argues that pedagogical beliefs play an important role in developing teachers' sense of competence and hence in their decisions and actions, among which a clear connection between pedagogical beliefs and self-efficacy. Further yet, as pedagogical beliefs might be viewed as an expression that ranges between "extremes" of two opposite education approaches - a pedagogical approach that involves (frontal) transferring of material to studentsin a highly structured system of theoretical framework and an constructivist-interactive approach that strives to enable the student to "discover" knowledge

15 Y.-C. Chan, N.-Y. Wong, Worldviews, religions, and beliefs about teaching and learning: perception of mathematics teachers with different religious backgrounds, Educational Studies in Mathematics, 2014, 87, 3, p. 251-277.

16 Ibidem.

17 S.E. Barrett, The Impact of Religious Beliefs on Professional Ethics.

18 R.A. Peterson, A Case Study of Grade 12 International School Students' Perceptions of The Impact of a Bible Curriculum and the Teachers' Delivery of that Bible Curriculum in a Christian International School, A Dissertation Presented in Partial Fulfillment of the Requirements for the Degree Doctor of Education, Liberty University, Lynchburg, 2017.

19 H. Fives, Exploring the relationships of teachers' efficacy, knowledge, and pedagogical beliefs: A multimethod study, University of Maryland, 2003.

20 Ibidem. 
- constructivist pedagogical beliefs were found to be positively associated with teachers' self-efficacy. ${ }^{21}$

As stated by Friedman \& Kass, ${ }^{22}$ self-efficacy should be viewed as teachers' expectations of how change is attainable. In this manner, teachers' beliefs and their self-efficacy both should be an expression of teachers' overall conduct including their ability to overcome difficulties, their personal well-being, success and efficiency in the work, or alternatively their feelings of burnout, stress, anxiety and, their ability to communicate and interact with other staff members. ${ }^{23}$

As Math teachers' satisfaction was found to be higher than other teach$\mathrm{ers}^{24}$ and similarly STEM ${ }^{25}$ teachers focus more on professional development, autonomy in teaching, and the behavior of their students, whereas non-STEM focus more on participation in school policies, ${ }^{26}$ it was also documented that teachers' beliefs are associated with teachers' work, satisfaction, perception of their profession, and interaction with their students and peers, even when they are not aware of it. ${ }^{27}$ The more cohesive teachers' beliefs are, the greater their satisfaction. ${ }^{28}$ Research involving Islam teachers in this regard is relatively scant. For the most part, such teachers were used as a population sample intended at measuring other aspects of teachers in a homogenic and relatively Islamic context (for example, two recent examples examined Islamic teachers' satisfaction using a sample of teachers from Bangladesh ${ }^{29}$ and from

${ }^{21}$ S.E. Anderson, J.G. Groulx, R.M. Maninger, Relationships among preservice teachers' technology-related abilities, beliefs, and intentions to use technology in their future classrooms, Journal of Educational Computing Research, 2011, 45, 3, p. 321-338.

${ }^{22}$ Y. Friedman, A. Kass, Teachers' self-efficacy: concept and measurement, A series of research tools, Jerusalem, Sald Institution, 2001.

${ }^{23}$ K. Lamoureux, Strategic Onboarding: Transforming New Hires into Dedicated Employees, Besrin \& Associates Research Bulletin, 2008, 3, 1.

${ }^{24}$ A. Bishay, Teacher motivation and job satisfaction: A study employing the experience sampling method, Journal of Undergraduate Sciences, 1996, 3, 3, p. 147-155; M. Kunter et al., Students' and mathematics teachers' perceptions of teacher enthusiasm and instruction, Learning and Instruction, $2008,18,5$, p. $468-482$.

${ }^{25}$ i.e. Science, Technology, Engineering, and Mathematics.

${ }^{26} \mathrm{~K}$. Wang et al., Examining the Differences between the Job Satisfaction of STEM and NonSTEM Novice Teachers with Leaving Intentions, EURASIA Journal of Mathematics, Science and Technology Education, 2018, 14, 6, p. 2329-2341.

${ }^{27}$ N. Barnes, H. Fives, C.M. Dacey, Teachers' beliefs about assessment, International Handbook of Research on Teachers' Beliefs, 2015, p. 284-300.

${ }^{28}$ L. Schrum, D.S. Niederhauser, N. Strudler, Competencies, Challenges, and Changes: A US Perspective on Preparing Twenty-First Century Teachers and Leaders, [in:] Competencies in Teaching, Learning and Educational Leadership in the Digital Age: Papers from CELDA 2014, Eds. J.M. Spector, D. Ifenthaler, D.G. Sampson, P. Isaias (a cura di), Cham, 2016; https://doi.org/10.1007/978-3319-30295-9_2, p. 17-32.

29 Ä. Leijen, M. Pedaste, Pedagogical Beliefs, Instructional Practices, and Opportunities for Professional Development of Teachers in Estonia, The Teacher's Role in the Changing Globalizing World, maggio 2018, p. 33-46. 
Pakistan $^{30}$ ). Still, religious pedagogical beliefs are positively associated with higher satisfaction levels among teachers. ${ }^{31}$

Teachers' pedagogical beliefs were found to be associated with burnout. For example, less favorable pedagogical beliefs of teachers regarding students' behavior and discipline issues were associated with higher levels of fatigue and mental exhaustion, as well as depersonalization and decreased personal performance. ${ }^{32}$ Similarly, the more teachers' beliefs regarding new pedagogic practices were negative, the higher their level of attrition and mental exhaustion was. ${ }^{33}$

Finally, teachers' pedagogical beliefs are positively associated with motivational aspects of their work. ${ }^{34}$ Pedagogical beliefs are considered as prerequisite to teachers' actions and decisions. Pedagogical beliefs might affect professional development decisions, educating styles, role perception and areas of responsibility and as such be the "driving force" behind teachers' behaviors in class. ${ }^{35}$ For example, as teachers held more positive and consolidate belief regarding the use of ICT, them and their students were more motivated to integrate technology into the work. ${ }^{36}$

\section{Method}

The proposed model argued that the teaching profession (Islam or mathematics) will have a differential effect on the pedagogical nature of the teachers' beliefs. In particular, it argues that teachers of Islamic studies will have a strong traditional belief and weaker constructive belief compared to teachers of secular studies, as well as teachers' functioning characteristics. Research questions were addressed using a descriptive approach, e.g. using quantitative statistical tools for identifying differences and descriptive of research groups.

${ }^{30}$ S. Batool, M.T.K. Farooqi, M.U. Islam, Measuring Teachers' Job Satisfaction: A Locale and Gender Based Comparison of Secondary School Teachers, International Journal of Innovation in Teaching and Learning (IJITL), Dicembre 2018, 4, 1; http://irigs.iiu.edu.pk:64447/ojs/index.php/ IJITL/article/view/313.

31 A.N. Hui et al., Do Demographic Characteristics Make a Difference to Psychological Well-Being among Secondary School Teachers in Hong Kong?, 16th Annual Meeting International Society for Quality-of-Life Studies: "Promotion of Quality of Life in the Changing World", 2018.

${ }^{32}$ K.D. Steiner, Teachers' Pedagogical Beliefs as Predictors of Teacher Burnout, Stanislaw Juszczyk, 2014, p. 177.

${ }^{33}$ W.J.G. Evers, W. Tomic, A. Brouwers, Burnout among Teachers Students' and Teachers' Perceptions Compared, School Psychology International, maggio 2004, 25, 2, p. 131-148.

${ }^{34}$ V. Mihaela, B. Alina-Oana, (When) Teachers' Pedagogical Beliefs are Changing?, ProcediaSocial and Behavioral Sciences, 2015, 180, p. 1001-1006.

${ }^{35}$ W.J.G. Evers, W. Tomic, A. Brouwers, Burnout among Teachers Students'.

${ }^{36}$ T.A. Cullen, B.A. Greene, Preservice teachers' beliefs, attitudes, and motivation about technology integration, Journal of Educational Computing Research, 2011, 45, 1, p. 29-47. 


\section{Subjects}

For this purpose, a quantitative approach was taken, based on distribution of questionnaires and collection of answers into a database that will be used to perform the statistical processing. To this end, 450 questionnaires were distributed among Mathematics and Islamic-religion teachers in various Arab schools in Northern Israel. However, only 153 full questionnaires were returned. 106 respondents (69\% of the respondents) are math teachers, and the rest (47 respondents, who constitute $31 \%$ of the sample) are teachers of Islamic studies. These groups define the research groups.

\section{Research tools}

Teachers' pedagogical beliefs was measured using $\mathrm{OECD}^{37}$ 8-item questionnaire, regarding two aspects of pedagogical beliefs: conservative-Traditional beliefs $(\alpha=.715)$ and Constructivist beliefs $(\alpha=.77)$. Teachers self-efficacy was measured using Friedman \& Kass $^{38}$ tool (29-itmes, $\mathrm{a}=.89$ ), teachers' satisfaction was measured using Carmeli \& Freund ${ }^{39}$ (9-items, $\left.a=.90\right)$, teachers' burnout was measured using Faigen et al. ${ }^{40} 14$-items $(\alpha=.91)$ questionnaire, and teachers; motivation was measured using Gange' et al. ${ }^{41} 12$-items $(\alpha=.86)$ questionnaire. All questionnaires were translated and adapted by the authors to adapt to the context of the research.

\section{Findings}

All teachers' conservative-traditional belief, constructivist beliefs, self-efficacy, satisfaction, burnout, and motivation levels are presented in

Fig. 1. As all variables were measured using a 5-items scales, teachers' self-efficacy is relatively high $(M=4.35)$ and their Satisfaction $(M=3.69)$ and Motivation level $(\mathrm{M}=3.51)$ are moderately-high. However, both teachers' Constructivist-beliefs $(\mathrm{M}=3.35)$ and teachers' Conservative-traditional beliefs $(\mathrm{M}=3.13)$ are only moderate. Also, as presented in

Fig. 1, teachers' burnout levels are moderate $(M=3.04)$.

${ }^{37}$ OECD, Chapter 4: Teaching practices, teacher's beliefs and attitudes, Creating Effective Teaching and Learning Environments: First Results from TALIS, OECD publications, 2009, p. 87-136.

${ }^{38}$ Y. Friedman, A. Kass, Teachers' self-efficacy.

39 A. Carmeli, A. Freund, Work commitment, job satisfaction, and job performance: An empirical investigation, International Journal of Organization Theory \& Behavior, 2003, 7, 3, p. 289-309.

${ }^{40}$ N. Faigen, R. Talmor, A. Erlich, The eroding combination: Factors of erosion in the work of physical education teachers in classrooms that integrate pupils with special needs, Trends, 2004, 43, 3, p. 519-545.

${ }^{41}$ M. Gagné et al., The Motivation at Work Scale: Validation Evidence in Two Languages, Educational and Psychological Measurement, agosto 2010, 70, 4, p. 628-646. 


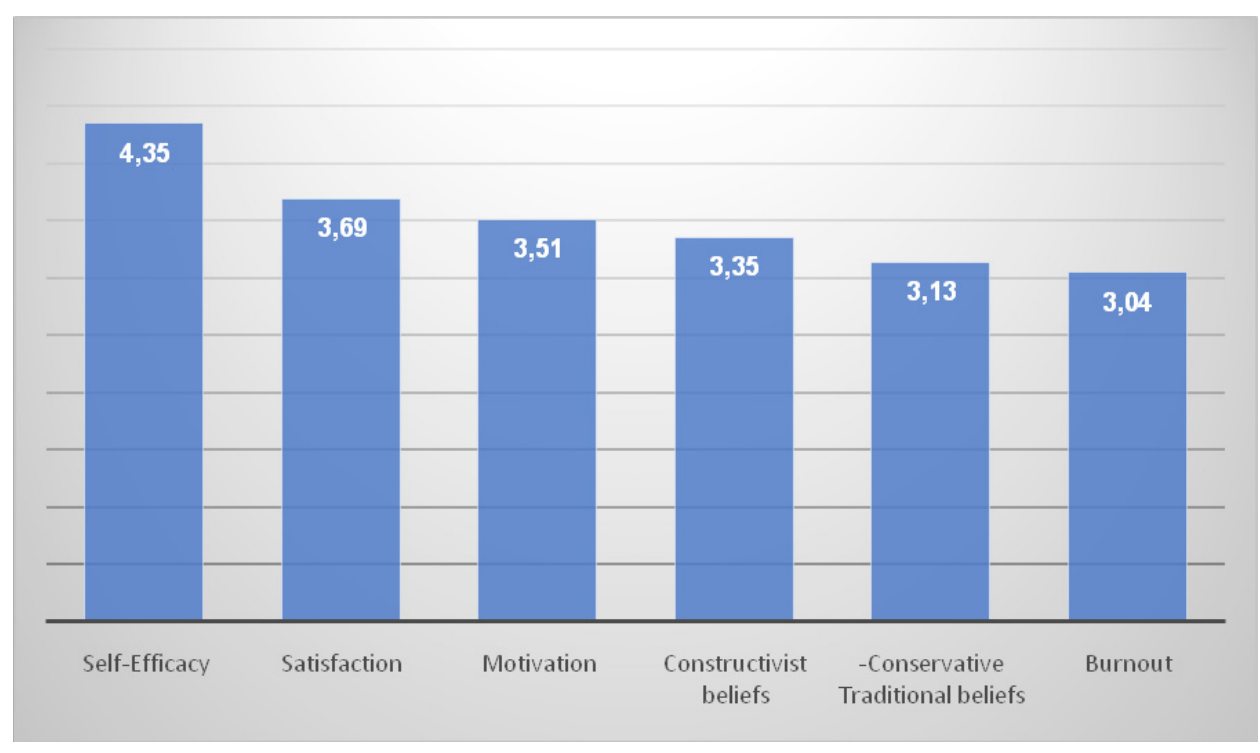

Fig. 1. Teachers Conservative-Traditional belief, Constructivist beliefs, Self-Efficacy, Satisfaction, Burnout, Motivation Means

Comparison of Arab Mathematics and Islam-religion teachers' conservative-traditional belief, constructivist beliefs, self-efficacy, satisfaction, burnout, and motivation is presented in Table 1 . As can be seen, no significant differences were found between the two research groups regarding teachers' conservative-traditional belief, constructivist beliefs, self-efficacy, burnout, and motivation.

Table 1

Mathematics teachers and Islam-religion teachers' conservative-Traditional belief,

Constructivist beliefs, Self-Efficacy, Satisfaction, Burnout, Motivation

- Mean comparisons

\begin{tabular}{|c|c|c|c|c|c|}
\hline & \multicolumn{4}{|c|}{ Research groups } & \\
\hline & \multicolumn{2}{|c|}{$\begin{array}{l}\text { Mathematics } \\
\text { teachers }\end{array}$} & \multicolumn{2}{|c|}{$\begin{array}{l}\text { Islam-religion } \\
\text { teachers }\end{array}$} & \\
\hline & M & SD & M & SD & $\mathrm{t}$ \\
\hline $\begin{array}{c}\text { Conservative-Traditional } \\
\text { belief }\end{array}$ & 3.12 & 0.46 & 3.16 & 0.43 & 0.496 \\
\hline Constructivist beliefs & 3.38 & 0.57 & 3.29 & 0.56 & 0.947 \\
\hline
\end{tabular}




\begin{tabular}{|c|c|c|c|c|c|}
\hline Self-Efficacy & 4.33 & 0.60 & 4.38 & 0.56 & 0.477 \\
\hline Satisfaction & 3.75 & 0.71 & 3.55 & 0.82 & $2.502^{*}$ \\
\hline Burnout & 3.02 & 0.94 & 3.10 & 1.05 & 0.471 \\
\hline Motivation & 3.48 & 0.65 & 3.58 & 0.62 & 0.853 \\
\hline
\end{tabular}

${ }^{*} \mathrm{p}<.05$.

However, mathematics teachers' satisfaction $(M=3.75, S D=.71)$ was found to be significantly $\left(\mathrm{t}_{150}=2.502, \mathrm{p}<.05\right)$ than Islam-religion teachers' $(M=3.55, S D=.82)$.

\section{Conclusions}

In this article, we have presented a thesis that there is a gap between the study of Islam as a humanistic, dogmatic and conservative field of study, and the study of mathematics, a field of "realistic" secular discipline, which today is perceived as the basis for successful integration in society, especially in the context of students' technological literacy. It was argued that teachers' overall set of attitudes toward education, which are briefly referred to as teachers' beliefs, is embodied not only in their private opinions but also in the choice of specialization field, the pedagogy that underlies the teaching of this field, and both would consequently conform to functioning characteristics, such as self-efficacy, satisfaction, burnout and motivation.

Math teachers' satisfaction was found to be higher than Islam teachers' satisfaction, as hypothesized. Like previous studies, ${ }^{42}$ these findings suggest that mathematics comes out as a more cohesive teaching profession, providing teachers with more autonomy in teaching, and in interacting with their students, while Islam teaching focus more on participation in school policies..$^{43}$

However, contrary to the hypotheses, mathematics teachers and Islam teachers' pedagogical beliefs as well as their self-efficacy, burnout and motivation did not differ. These findings suggest that the static, fixed perception of religion studies as conservative and outdated ${ }^{44}$ is no longer valid. In its' place, one can identify change among teachers of Islamic studies - a change in which these teachers, like teachers in other disciplines, adopt modern liberal ap-

${ }^{42}$ A. Bishay, Teacher motivation; M. Kunter et al., Students' and mathematics teachers'; K. Wang et al., Examining the Differences between.

${ }^{43} \mathrm{~K}$. Wang et al., Examining the Differences between.

${ }^{44} \mathrm{~S}$. Ilues, The pedagogical beliefs of Bible and the Oral Law teachers. 
proaches that place emphasis on pedagogy and modern educational content. As such, this might indicate a change within the Arab society which deviates from the traditional Islamic halakhic approach that focuses almost entirely on religious studies and adopts a more modernized and liberal educational approach which is centered on a Western education model and secularism.

\section{BIBLIOGRAPHY}

Anderson S.E., Groulx J.G., Maninger R.M., Relationships among preservice teachers' technology-related abilities, beliefs, and intentions to use technology in their future classrooms, Journal of Educational Computing Research, 2011, 45, 3.

Barnes N., Fives H., Dacey C.M., Teachers' beliefs about assessment, International Handbook of Research on Teachers' Beliefs, 2015.

Barrett S.E., The Impact of Religious Beliefs on Professional Ethics: A Case Study of a New Teacher, Canadian Journal of Education; Toronto, 2015, $38,3$.

Batool S., Farooqi M.T.K., Islam M.U., Measuring Teachers' Job Satisfaction: A Locale and Gender Based Comparison of Secondary School Teachers, International Journal of Innovation in Teaching and Learning (IJITL), Dicembre 2018, 4, 1; http:/ /irigs.iu.edu.pk:64447/ojs/ index.php/IJITL/article/view/313.

Bishay A., Teacher motivation and job satisfaction: A study employing the experience sampling method, Journal of Undergraduate Sciences, 1996, 3, 3.

Carmeli A., Freund A., Work commitment, job satisfaction, and job performance: An empirical investigation, International Journal of Organization Theory \& Behavior, 2003, 7, 3.

Central Bureau of Statistics, Teaching Staff in Secondary Education by Selected Characteristics, Yearly census report, Jerusalem, Israel, Central Bureau of Statistics, 2019 (in Hebrew).

Chan Y.-C., Wong N.-Y., Worldviews, religions, and beliefs about teaching and learning: perception of mathematics teachers with different religious backgrounds, Educational Studies in Mathematics, 2014, 87, 3.

Cullen T.A., Greene B.A., Preservice teachers' beliefs, attitudes, and motivation about technology integration, Journal of Educational Computing Research, 2011, 45, 1.

Evers W.J.G., Tomic W., Brouwers A., Burnout among Teachers Students' and Teachers' Perceptions Compared, School Psychology International, maggio 2004, 25, 2.

Faigen N., Talmor R., Erlich A., The eroding combination: Factors of erosion in the work of physical education teachers in classrooms that integrate pupils with special needs, Trends, 2004, 43, 3, (in Hebrew).

Fisher Y., Exploration of values: Israeli teachers' professional ethics, Social Psychology of Education, 2013, 16, 2.

Fives H., Exploring the relationships of teachers' efficacy, knowledge, and pedagogical beliefs: A multimethod study, PhD Thesis, University of Maryland, 2003.

Fives H., Gill M.G., International handbook of research on teachers' beliefs, Routledge, 2014.

Friedman Y., Kass A., Teachers' self-efficacy: concept and measurement, A series of research tools, Jerusalem, Sald Institution, 2001 (in Hebrew).

Gagné M., Forest J., Gilbert M.-H., Aubé C., Morin E., Malorni A., The Motivation at Work Scale: Validation Evidence in Two Languages, Educational and Psychological Measurement, agosto 2010, 70, 4 .

Hui A.N., Shek D.T., Wu J.K., Wu M.J., Chan L.K., Do Demographic Characteristics Make a Difference to Psychological Well-Being among Secondary School Teachers in Hong Kong?, 
16th Annual Meeting International Society for Quality-of-Life Studies: "Promotion of Quality of Life in the Changing World", 2018.

Ilues S., The pedagogical beliefs of Bible and the Oral Law teachers of girls in the religious high school, PhD Thesis, Ramat-Gan, Bar-Ilan University, 2004 (in Hebrew).

Kunter M., Tsai Y.-M., Klusmann U., Brunner M., Krauss S., Baumert J., Students' and mathematics teachers' perceptions of teacher enthusiasm and instruction, Learning and Instruction, 2008, 18, 5 .

Kupfferberg I., Niederland D., To be a teacher in Israel in the 21st century, [in:] Building Professional Identity: Professional training and development processes for teachers in Israel, Eds. R. Kloyer, L. Kozminsky, Tel Aviv, Moffett Institute, 2012 (in Hebrew).

Lamoureux K., Strategic Onboarding: Transforming New Hires into Dedicated Employees, Besrin \& Associates Research Bulletin, 2008, 3, 1.

Leijen Ä., Pedaste M., Pedagogical Beliefs, Instructional Practices, and Opportunities for Professional Development of Teachers in Estonia, The Teacher's Role in the Changing Globalizing World, maggio 2018.

Mahajhna A., Kfir D., Islamic Studies in the Age of Globalization: The Case of Arab Teacher Training in Israel, Beit Berl Academic College, 2012 (in Hebrew).

Mihaela V., Alina-Oana B., (When) Teachers' Pedagogical Beliefs are Changing?, Procedia-Social and Behavioral Sciences, 2015, 180.

Ministry of Education, Opening 2019-2020 school year public announcement by Israel's Education minister, (in Hebrew), 2019; https://edu.gov.il/owlHeb/AboutUs/newyeartahaa/Pages/year-opening.aspx.

OECD, Chapter 4: Teaching practices, teacher's beliefs and attitudes, Creating Effective Teaching and Learning Environments: First Results from TALIS, OECD publications, 2009.

Peterson R.A., A Case Study of Grade 12 International School Students' Perceptions of The Impact of a Bible Curriculum and the Teachers' Delivery of that Bible Curriculum in a Christian International School, A Dissertation Presented in Partial Fulfillment of the Requirements for the Degree Doctor of Education, Lynchburg, VA, Liberty University, 2017.

Schrum L., Niederhauser D.S., Strudler N., Competencies, Challenges, and Changes: A US Perspective on Preparing Twenty-First Century Teachers and Leaders, [in:] Competencies in Teaching, Learning and Educational Leadership in the Digital Age: Papers from CELDA 2014, Eds. J.M. Spector, D. Ifenthaler, D.G. Sampson, P. Isaias (a cura di), Cham, Springer International Publishing, 2016; https:/ / doi.org/10.1007/978-3-319-30295-9_2.

Steiner K.D., Teachers' Pedagogical Beliefs as Predictors of Teacher Burnout, Stanislaw Juszczyk, 2014.

Veissblei E., Vieneger A., The Education System in Israel - Selected Issues in the Field of the Knesset's Education, Culture and Sports Committee, Special report to Education, Culture, and Sport committee, Israel Knesset, 2015 (in Hebrew).

Wang K., Chen Z., Luo W., Li Y., Waxman H., Examining the Differences between the Job Satisfaction of STEM and Non-STEM Novice Teachers with Leaving Intentions, EURASIA Journal of Mathematics, Science and Technology Education, 2018, 14, 6. 